\title{
The Making of Buck Creek: Country Life Reform, Religion, and Rural School Consolidation
}

\section{DAVID R. REYNOLDS}

A CAREFUL OBSERVER traveling west along County Road D-47 from Hopkinton to Ryan in Union Township in southern Delaware County, Iowa, today will notice a small sign by the side of the road announcing "BUCK CREEK Community POP. 32." Within a few hundred yards, less than a half-dozen houses huddle around a small Methodist church. About 150 yards west of the church stands a large dilapidated brick building, a former school with gymnasium attached, presently used to store the farm equipment and grain of one of the bigger farm operations in the area. "BUCK CREEK CONSOLIDATED SCHOOL" is emblazoned on a large cement tablet prominently displayed on the front of the building above its main entrance.

The Buck Creek Methodist Church and the Buck Creek Consolidated School were once imbued with far more significance of place, of community, and even of personal identity for people in southern Delaware County than they are now. The Buck Creek church and school were once prominent social actors in themselves, giving definition and meaning to a larger and, in a sense, more cosmopolitan place called Buck Creek. That Buck Creek did not require a sign announcing its presence; it was visible in the social landscape, but one had to know what to look for and realize that place is defined by process as much as by location.

I thank the University of Iowa Press for granting permission to draw freely from my book, There Goes the Neighborhood: Rural School Consolidation at the Grass Roots in Early Twentieth-Century Iowa, copyright 1999 by University of Iowa Press.

THE ANNALS OF IOWA 58 (Fall 1999). (C) The State Historical Society of Iowa, 1999. 
The processes that defined Buck Creek in the first two decades of the twentieth century were those that characterized the so-called Progressive Era. That is a period of critical importance for those seeking to understand the emergence of new forms of social and economic regulation and control in the United States. Rapid social and economic change was accompanied by the cultural and ideological forces of modernism, which increasingly took hold of the American psyche during that period. The federal and state governments began to assume their modern bureaucratic forms. A professional middle class rose to fill new positions of authority in both civil society and the state and transformed the structure of power in the nation. The introduction and widespread acceptance of new transportation and communication technologies changed the social meanings and valuations of space and time irreversibly, while space-time itself became more compressed as revolutions in the control and use of time annihilated geographical space. Leading these cultural, political, and material transformations were a new set of elites - the Progressives-who were optimistic that under their leadership the powers of the state could harness the productive capacity of capitalism to ensure the material progress of all classes. Perhaps no terms better capture the economic and political ideology of the Progressive Era than progress and consolidation. ${ }^{1}$ Material progress was the Progressives' desired goal; institutional and organizational consolidation the means to achieve it.

The Country Life movement was arguably the Progressive Era's most important rural reform movement. Its leaders sought to identify and implement an alternative future for rural people, especially for farm families. They believed that through appropriate spatial and economic planning and public investment, a new form of rural community combining the advantages of both city and country could be created. Such communities would be defined physically by the trade areas of either new or revitalized villages and small towns-what many Country Lifers referred to as "country towns." ${ }^{2}$ The first step was to bring to-

1. For a similar perspective, see Lawrence Goodwyn, Democratic Promise: The Populist Moment in America (New York, 1976), vii-xv.

2. See for example, Wilbert L. Anderson, The Country Town: A Study of Rural Evolution (New York, 1906). An excellent recent treatment is Mary Neth, Pre- 
gether farmers and people from the smallest urban places serving as primary markets and retail centers for farm families to form new, more spatially extensive, yet still essentially "ruralminded" communities. According to Country Life ideology, country towns would be the most appropriate sites for consolidating the social, religious, and educational activities of these new rural communities. With this consolidation of rural social relations at a single place, both farmers and townspeople would recognize their common social and economic problems and seek appropriate solutions to them. Although not explicit in the rhetoric of the Country Life movement, its proponents expected these country towns to be Protestant places.

Previous research on the Country Life movement has emphasized the intellectual roots of the movement, the social backgrounds of its principal architects and operatives, and its ideological staying power, particularly among the new urban middle class in America. ${ }^{4}$ It has, however, failed to illuminate the central role that one particular reform-the consolidation of rural schools-was to play in engineering the desired transformation of rural life, especially in the Midwest. ${ }^{5}$ The result is that relatively little is known about how this important reform was actually attempted in different localities. Who were the key actors at the grass roots? How were they recruited? How can the conflicts surrounding consolidation best be characterized? Given that efforts to consolidate rural school districts in the

serving the Family Farm: Women, Community, and the Foundations of Agribusiness in the Midwest, 1900-1940 (Baltimore, 1995), 97-146.

3. James H. Madison, "Reformers and the Rural Church, 1900-1950," Journal of American History 73 (1986), 645-68.

4. See for example, William L. Bowers, The Country Life Movement in America, 1900-1920 (Port Washington, NY, 1974); and David B. Danbom, The Resisted Revolution: Urban America and the Industrialization of Agriculture (Ames, 1979).

5. Important exceptions are David B. Danbom, "Rural Education Reform and the Country Life Movement, 1900-1920," Agricultural History 53 (1979), 462-74; James H. Madison, "John D. Rockefeller's General Board of Education and the Rural School Problem of the Midwest, 1900-1930," History of Education Quarterly 24 (1984), 181-99; Merwin Swanson, "The 'Country Life Movement' and the American Churches," Church History 46 (1977), 358-73; and William A. Link, A Hard Country and a Lonely Place: Schooling, Society, and Reform in Rural Virginia, 1870-1920 (Chapel Hill, NC, 1986). 
Midwest became one of the most significant social movements of the Progressive Era, these are serious lacunae.

Elsewhere, I argue that there was also another set of reformers in the Midwest advocating rural school consolidation but for different reasons. ${ }^{6}$ Leaders in the new field of educational administration saw school consolidation as a means of improving the quality of elementary education in rural areas and of expanding the reach of the public high school into the countryside. By about 1910, these educational reformers had joined forces with the Country Lifers, combining their considerable rhetorical and political skills to form a relatively cohesive social movement. For a time, they jointly succeeded in creating a powerful discourse in support of rural school consolidationone in which consolidation appeared to be the solution to a host of country life problems. ${ }^{7}$

6. See David R. Reynolds, There Goes the Neighborhood: Rural School Consolidation at the Grass Roots in Early Twentieth-Century Iowa (Iowa City, 1999), chaps. 1-3.

7. Rural school consolidation was resisted vigorously throughout the region and resisted successfully in a number of places. Nonetheless, relatively little is known about why resistance occurred where it did or why it took the particular forms it did. This has not prevented contemporary educational historians from trying to characterize this resistance based principally on documentation left behind by the supporters of reform. Most of the alternative interpretations offered cleave into two polar extremes. One interprets resistance to school reform as the expression of a fundamental allegiance to local autonomy and Jeffersonian democracy; the other interprets it as the expression of a deeply ingrained, regionally specific, antiintellectualism evincing profoundly antidemocratic tendencies. Paul Theobald, in Call School: Rural Education in the Midwest to 1918 (Carbondale, IL, 1995), provides the most detailed account of these two interpretations in the specific context of midwestern rural resistance to common schools in the nineteenth century and to a lesser extent to township consolidation in the twentieth. See also Paul Theobald, "Democracy and the Origins of Rural Midwest Education: A Retrospective Essay," Educational Theory 38 (1988), 363-67. According to Theobald, Wayne E. Fuller, The Old Country School: The Story of Rural Education in the Middle West (Chicago, 1982); and Madison, "Rockefeller's General Board of Education," represent much of the recent work appearing to champion resistance as an expression of local democracy. Theobald's perspective is closer to the antiintellectual-antidemocratic interpretation of the educational historians writing earlier in the twentieth century. He hypothesizes that major landowners in the rural neighborhoods of the Midwest fought to retain control over the rural independent school districts so that they could continue to manipulate local school policy so as to keep women and tenants from competing with them for the control of local land markets (Theobald, Call School, 83). While correctly identifying the school as a key neighborhood institution, Theobald overstates the extent to which 
From 1912 to 1921, Iowa was the center of national attention as state and local leaders attempted to implement their preferred variant of rural school consolidation-one that sought to replace the myriad one-room country schools with a much smaller number of new "consolidated" schools, containing the elementary grades and four years of high school, to be located either in the open country or in villages and small towns. ${ }^{8} \mathrm{Al}-$ though achieving some success initially, the movement largely failed, both as an educational innovation and as the institutional means of creating the country towns that were to usher in the new forms of rural community hoped for by Country Lifers.

The following case study of Buck Creek in Delaware County, Iowa, helps to clarify why the movement failed. It focuses on the building of a new rural community of the sort envisioned by the leaders of the Country Life movement. The communitybuilding effort at Buck Creek was initiated by a local Country Life activist, a Methodist minister. Once it became clear that the project also entailed rural school consolidation, a lengthy debate ensued over the nature of the rural community that was being constructed and the roles of the church and the school in its creation and reproduction. Although that debate had some unique elements, variants of it occurred in practically every rural community in the state in the first quarter of the twentieth century. ${ }^{9}$ Debates over rural school consolidation then as now

control over it could be used to pursue the parochial material interests of dominant families in rural neighborhoods. He also fails to recognize that the rural church was more effective at keeping women and in-migrants, especially tenant farmers, landless and "on the move." In There Goes the Neighborhood, I argue that the formation of a consolidated school district could be a much more effective way of regulating local land markets than the control of the small country school district ever could have been.

8. More than 1,000 villages with populations below 800 were identified as the "natural centers" for consolidated schools-as the new "country towns" that Country Life reformers hoped could be engineered through consolidation. F. A. Welch, "Some Problems of the Village School," Midland Schools 35 (1921), 14748; Macy Campbell, "A Brief History of Consolidation in Iowa," Bulletin of the Iowa State Teachers' College, Department of Rural Education 22.(1921), 3-16.

9. For a more complete history and historiography of the rural school consolidation movement in Iowa, see Reynolds, There Goes the Neighborhood, esp. chap. 5 . 
were at least as much about the nature of social relations in rural communities and social power in the larger society as they were about the quality of education.

BEFORE 1912, the predominant social relationships in the various rural neighborhoods in Union Township revolved around farm work. Being a good neighbor entailed conforming to expected ways of interacting with other people with whom one came into regular contact while working and living in the same small area. These expectations extended to the sharing of capital goods and labor in matters incidental to production, to participation in group-based recreational activities, to cooperation in the structuring of childhood socialization experiences, and to the conduct of leisure time activities of adults or whole families. Good working relationships with one's neighbors were necessary adjuncts to the family- and neighborhood-based system of commercial agriculture then practiced. As a person who grew up in the Buck Creek area during this period put it, "you can't get along without your neighbor no matter what he is, black or white, red or green. You can't get along no matter where you are without your friends." ${ }^{10}$ Although who one's neighbors were was based on spatial proximity within a bounded territory, the neighborhood itself was socially defined by the juxtaposition of the biographies of individual residents. It was here that country school districts assumed considerable importance, for they provided a dominant context for the daily lives of most farm family members. They were the primary places where neighboring and many other activities occurred.

During the two decades bracketing the beginning of the twentieth century, Buck Creek was one such rural neighborhood in Union Township. Encompassing almost $3 \frac{1}{2} 2$ square miles, its boundaries were coincident with what was then officially Subdistrict No. 3 of the School Township of Union, referred to locally as the Buck Creek district-one of the eight subdistricts,

10. Leslie Tumey, interview by author, Hazel Green Township, Delaware County, Iowa, 24 May 1991. For further discussion of the "neighborhood system of family farming" and its centrality in the political economy of the Midwest, see Reynolds, There Goes the Neighborhood, chap. 2, and Neth, Preserving the Family Farm, chap. 2. 
FIGURE 1

UNION AND HAZEL GREEN SCHOOL TOWNSHIPS, 1900-1915
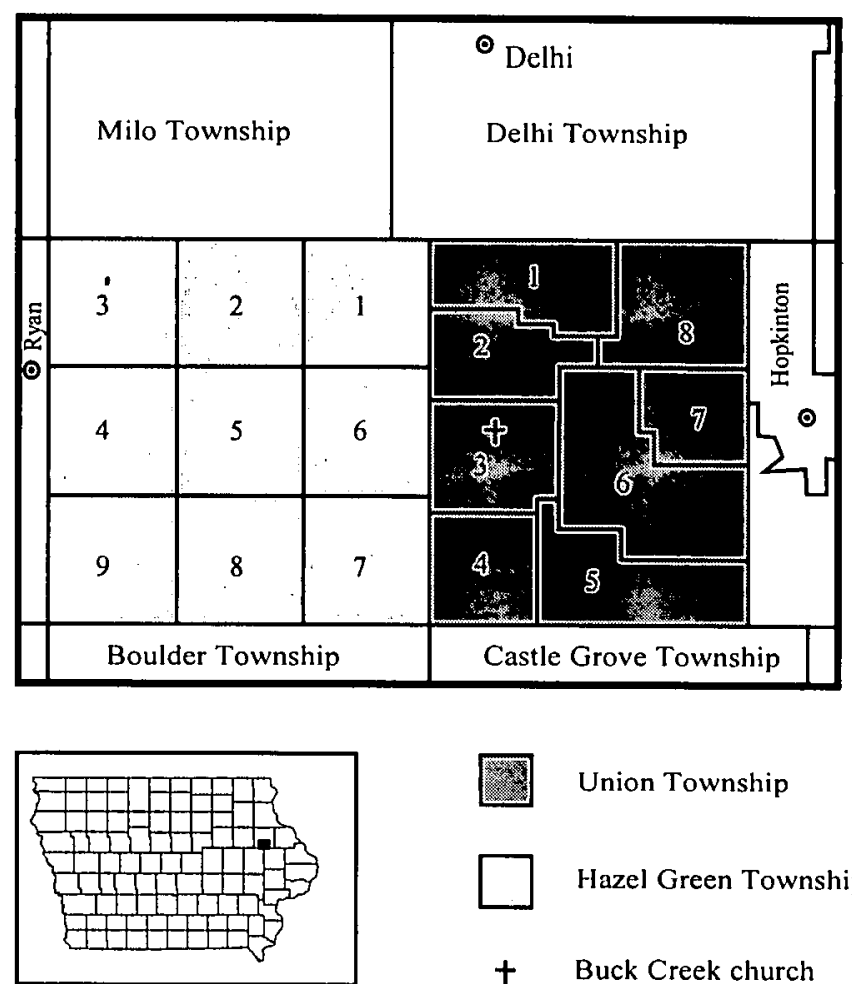

Union Township

Hazel Green Township

$+\quad$ Buck Creek church

Map by Peter Li

each with its own one-room school, composing the School Township of Union (fig. 1). Until 1912, most of the 67 members of the Buck Creek Methodist Episcopal Church were residents of this neighborhood. Other neighborhoods roughly coincident with the school township subdistricts of the area included the Dufoe, Kelley, River Valley, and Upper Buck Creek neighborhoods of Union Township and the Harrington, Hazel Green, and Wilson neighborhoods in Hazel Green Township. Only one subdistrict in the area, Union No. 6 (referred to locally as the Bacon district) failed to function as a neighborhood. Indeed, this subdistrict 
was probably the most socially complex, consisting of parts of several neighborhoods. Residents of the two sections in its southeastern corner identified with the Dufoe or Castle Grove neighborhoods, while those in the $2 \frac{1}{2}$ sections along its western edge increasingly thought of themselves as members of the Buck Creek neighborhood after 1912. Those in the remaining territory tended to see themselves as part of rural Hopkinton."

In the larger, roughly 50-square-mile area from which the Buck Creek church drew its members, there were (and are) no towns or villages. ${ }^{12}$ Four general stores and two small creameries were located near the edges of the area, but they did not form the nucleus of anything more than the usual crossroads settlement of three or four farm families. Hopkinton (pop. 797 in 1910) was the primary trade and marketing center for most of Union and Castle Grove Townships, and Ryan (pop. 511) for most of Hazel Green Township. The distance between these two towns, almost 14 miles, was traversed by roads that became impassable by automobile for several days at a time during rainy periods, especially in late winter and spring. This left the two churches in the area-the Buck Creek Methodist Episcopal Church and the Immaculate Conception Catholic Church-as the only other preexisting institutions with any potential to challenge or transcend the traditional neighborhood and to become the organizational bases for the creation of a larger, more spatially extensive community consciousness. Indeed, if there was any rural "community" in the area that was spatially more extensive than that of the traditional neighborhood, it was the Immaculate Concep-

11. This information was derived from interviews with 14 long-term residents or former residents of the area whose families were active participants in, or otherwise had knowledge of, the controversies surrounding the formation of a consolidated school district in the Buck Creek area from 1919 through 1923; from the author's examination of the "neighborhood" news columns appearing in the Hopkinton Leader; and from the correspondence of Frank M. Joseph, Deputy State Superintendent of Public Instruction, in 1915 pertaining to an unsuccessful attempt to form a consolidated school district at Hopkinton in 1915, in the Letter Books of the Superintendent of Public Instruction, State Archives, State Historical Society of Iowa, Des Moines.

12. The area of concern consists of all of Union Township, the eastern third of Hazel Green Township, and the northern third of Castle Grove Township. Union and Hazel Green Townships are in Delaware County, while Castle Grove is in Jones County. 
tion Parish. Dominated by several Irish Catholic families, the parish covered most of the territory of the four country school subdistricts surrounding it-two in Union Township and two in Castle Grove Township.

In the decade of most interest here, 1912-1921, the Buck Creek Methodist Episcopal Church, under the leadership of a charismatic minister imbued with an evangelical variant of Country Life ideology, set about doing the Catholic community one better by creating a larger Protestant counterpart. It did so by articulating its own locally nuanced version of how the rural church could become the key agent in rural social and economic change by implementing a series of measures designed to instill in the residents of the area a new kind of rural community consciousness. The effort succeeded by and large, but had some important and unforeseen consequences.

THE CHARISMATIC MINISTER was the Reverend Gilbert J. Chalice. In 1912, at the age of 35, he came to serve the Methodist Episcopal church in Hopkinton and the one in Buck Creek whence he began his remarkable ministry. ${ }^{13}$ Upon arriving in Hopkinton, Chalice set out to build up both Methodist parishes in his charge. It was clear almost from the outset, however, that he thought his talents and interests could be better deployed in the Buck Creek church. As he put it in one of his early sermons,

13. Chalice was born in Plymouth, England, in 1877. According to church records, he was selected as one of 13 from among 180 candidates to be sent by the Methodist Church of England to Ontario, Canada, for further seminary training and "pioneer service" on the Canadian prairies for the Home Mission Board of Canada. From Ontario he was sent directly to the Wesley Seminary in Winnipeg. After graduating, he spent a few months preaching in rural parishes on a circuit on the Canadian prairies before switching to "city work." In 1909, while still in Canada, he married, shortly thereafter moving with his new bride, Sada, to Mason City, where he attended the Upper Iowa Conference of the Methodist Episcopal Church in the fall of 1909. There he was received into the conference on trial and ordained deacon. Prior to arriving in Hopkinton he served the Methodist Episcopal Church in Fairfax, near Cedar Rapids. Centennial Committee of Buck Creek United Methodist Church, Buck Creek United Methodist Church Centennial, 1875-1975 (Monticello, 1975), 6; Buck Creek Parish (Philadelphia, 1919), 10; and Official Records of the Ninety-First Session of the Upper Iowa Annual Conference of the Methodist Church (Mount Vernon, 1946), 618-19. Both the centennial history and Buck Creek Parish are available in the Delaware County Historical Museum, Hopkinton. 
"The farmer is a custodian of the nation's morality with rural people more susceptible to religious influence because he works in God's soil therefore a great need lies in the pastor's endeavor to supply spiritual help and assist to the higher life." Chalice later recalled that as he faced his congregation for the first time he began to see the true potential of the rural church in community rebuilding. "Although the church, feeble in its ministry to the community and decadent in appearance, had fallen down on its job, there still existed a most remarkable community spirit. For in that congregation was a large percentage of young people, bright, keen and intelligent, who were only waiting until they should be assigned some definite task to rebuild the community."

Chalice began his ministry in Buck Creek with a series of Methodist camp meetings during which he preached every night for three weeks (including the three Sundays he also had to be in Hopkinton for morning services). Many farm families from the surrounding area pitched their tents on land reserved for that purpose down by the creek. ${ }^{15}$ Billed as "special community meetings" directed at the farm families in the area, they were old-fashioned religious revivals, intentionally evangelistic in tone and content. Many came out of curiosity to see the new preacher and his wife and to hear how "old-time" religion sounded when delivered with an English accent. ${ }^{16}$

Having aroused the curiosity of people in the area and captured their attention, Chalice began preparations to launch a program of church revitalization and rural community building. In this work he drew heavily on the writings of American theologians and rural sociologists linked closely to the Country Life movement. Excerpts from some of Chalice's more memorable sermons saved by parishioners strongly suggest that while he subscribed to most of the tenets of the Country Life movement, his philosophy was a complex mixture of traditional Methodism, Progressivism, and agrarian utopianism. Whatever that mixture, it found a receptive audience among Protestant farm

14. Buck Creek Parish, 6, 2.

15. Directory of the Buck Creek United Methodist Church, 1989 (available in the Delaware County Historical Museum, Hopkinton).

16. Roscoe Willard, interview by author, Hopkinton, 20 June 1994. 
families in the area. By 1914, Chalice had resigned from his Hopkinton charge to become the full-time pastor of the Buck Creek church at a salary almost $\$ 300$ higher than he had received previously for serving both parishes. $\mathrm{He}$, his wife, and their young daughter took up residence in a new parsonage next to the church. ${ }^{17}$

From the fall of 1914 through the fall of 1918, 137 new members joined the Buck Creek church, bringing its total active membership to $176 .^{18}$ By 1918 , almost every social gathering of any consequence held in Union Township was in one way or another linked to the activities of the Buck Creek church. Most noteworthy of these was the annual Buck Creek Fair held each year in late August or early September. Generally of three days duration, this was the big social event of the year, attracting hundreds of people from all over southern Delaware County. Consistent with Chalice's Country Life philosophy, the first day of the fair, usually a Sunday, began with a special religious service highlighted by a noted evangelist. The afternoon featured religious music, more preaching, and religious "carrying on" in the best tradition of Methodist camp meetings and revivals of that era. The second day, designated "Farmer's Day," was devoted to agricultural exhibits, demonstrations, and contests. All of these activities were gender specific. Those for the men stressed agricultural productivity and special achievements, while those for women stressed painting, needlework, and domestic science. Ribbons and prize money donated by the State Department of Agriculture went to the top entries in production and craft categories. The last day of the fair was given over to social, cultural, and recreational events, complete with a parade,

17. Mr. and Mrs. Freeman Smith, interview by author, Union Township, Delaware County, 24 May 1991; Buck Creek Parish, 10; Centennial Committee, Buck Creek United Methodist Church Centennial, 6. For additional information, see Reynolds, There Goes the Neighborhood, chap. 8.

18. Buck Creek Parish, 13. Other sources place the Buck Creek church's membership at 250 at this time. See Delaware County Leader, 24 April 1975. A dated clipping is in a scrapbook of newspaper clippings kept by the late Dora Winch focusing on the activities of Buck Creek residents and especially those of the Buck Creek church from the early 1920s through the 1980s. The scrapbook is in the Delaware County Historical Museum, Hopkinton. See also Centennial Committee, Buck Creek United Methodist Church Centennial, 6. 
band music, athletic contests, a dinner, and lectures designed to provide both entertainment and instruction. Other accoutrements typically found at county fairs, such as the beer tent, sideshows, games of chance, and dancing, were strictly excluded. ${ }^{19}$

While the Buck Creek Fair was the big event and the one that put Buck Creek in the imagined geographies of most persons in Delaware County, three of its elements-evangelism, progressive agricultural practice, and "wholesome" recreational activity-permeated all of the Buck Creek church's many activities. An effective evangelist as well as a Country Life reformer, Chalice's ministering profoundly affected the lives of many people in the Buck Creek area. ${ }^{20} \mathrm{He}$ even succeeded in eliminating that anathema to midwestern Methodism, which had hitherto thrived in the Buck Creek area-Sunday baseball. Instead, the church's Epworth League chapter fielded its own baseball team, which played on a well-maintained field behind the church every Saturday. Chalice also helped secure the cooperation of the State Library Commission in creating a traveling library for Union Township based in and run by the Buck Creek church. ${ }^{21}$

At that time tenants operated roughly half of the farms in Union Township. As was becoming increasingly common in Iowa at that time, tenants occupied farmland at least as good as and probably better in quality than that worked by owners. ${ }^{22}$ Although some tenants in the area moved frequently, they seldom moved very far: most were the sons, daughters, brothers, or sisters of those already residing there, and intimate local

19. See Buck Creek Parish, 1, and a newspaper clipping in Dora Winch's scrapbooks, dated 1955, titled "Buck Creek Methodist Church will observe the 50th anniversary of an unusual event-a church-sponsored community fair."

20. In perusing Dora Winch's scrapbooks (some are also available in the Hopkinton Public Library), one is struck by the frequency with which obituaries of Buck Creek area residents made specific mention of both the Buck Creek church and Reverend Chalice.

21. Buck Creek Parish, 17.

22. All of the persons interviewed in the Buck Creek area agreed with this generalization. Some also noted that Catholic families were renting land previously worked by Protestant families, which was a major source of concern within the Buck Creek church at the time. 
knowledge was a prerequisite for "getting a good farm." ${ }^{23}$ Thus, any strategy designed to improve the quality of rural community life would have to be sensitive to who those tenants were and how they fit into the local social structure. Chalice and leaders of the Buck Creek church therefore took a particular interest in each year's "crop" of new tenants. Soon after the March 1 "moving day" each spring, the Ladies' Aid Society and the men's Brotherhood held a banquet to welcome newcomers to the area. Not content simply to wait and see who the new renters in the area were each year, Chalice urged major landowners in the church to be proactive and lease only to tenants who would be "good members of the community." Most parishioners interpreted this to mean that they should give preference to those who would become active in the Buck Creek church. Catholic families, even if they were related to other Catholic families already living in the area, were obviously disadvantaged. ${ }^{24}$ At least initially, this did not lead to any overt manifestations of anti-Catholic sentiment locally. Indeed, Chalice's personal relations with Catholic men in the area seem to have been cordial. For instance, he numbered among his friends Frank King, a major landowner and head of a prominent Catholic family in the Upper Buck Creek neighborhood. ${ }^{25}$

Sensitive to the strong tradition of neighboring in the area and wishing to make the church a vital part of that tradition, Chalice established a "visiting committee" responsible for notifying him of matters bearing on the welfare of the community. Besides informing him of the arrival of any new residents in the area, they also notified him of shut-ins and of those who were sick or otherwise incapacitated. If, due to illness or other causes beyond his control, a farmer fell behind in his farm work, Chalice and the male members of the visiting committee offered their help. For example, C. J. "Cliff" Willard, a farmer living about a mile north of the Buck Creek church, suffered a barn fire that destroyed most of his field equipment when he was barely

23. Winona (Miles) Flannagan and Jay Flannagan, interviews by author, Hopkinton, 3 and 4 September 1994.

24. Willard and Flannagans, interviews.

25. Smith, interview. 
a third of the way through his corn harvest. To his surprise, Chalice and a group of men with several teams of horses in tow arrived the next morning to help him complete the harvest. ${ }^{26}$ Gradually, the Buck Creek church usurped the role that the rural neighborhood had traditionally performed in family farming, at least for Protestants in the area.

As a Country Life reformer and rural community builder, Chalice missed few opportunities to bring innovations in scientific agriculture and farm management to the attention of his congregation. Knowing that "no church could thrive in a nonproductive section or in a community where the labor income was small," he actively sought help from the Extension Division of the State Agricultural College in the form of written materials, public speakers, traveling exhibits, and assistance in setting up demonstration projects on a wide range of topics: silo construction, herd improvement, fruit growing, poultry raising, canning, rural health, and sanitation. This was relatively easy to accomplish because the Extension Division at Ames was already providing instruction and extension services under the auspices of nearby Lenox College, in Hopkinton. ${ }^{27}$ Chalice's interest in the adoption of more scientific agricultural practices and progressive farming was not so narrowly instrumentalist as to be concerned only with augmenting the incomes of his parishioners. He seems genuinely to have believed that the more widespread adoption of these innovations coupled with a spiritual reawakening in the countryside could combine to create something of a rural utopia in the Corn Belt. As Chalice declared in one of his early sermons in Buck Creek, "with the aid of horticulture, domestic science, and household economics the farm home can be "Heaven on Earth." ${ }^{28}$

EVEN BEFORE he became the resident pastor at Buck Creek in 1914, Chalice had begun pushing the congregation to "modernize" education in the area. It is not surprising, therefore, that

26. Willard, interview.

27. Buck Creek Parish, 11; William R. Ferguson, The Biography of Lenox College (Hopkinton, 1949), 25.

28. Buck Creek Parish, 6. 
it was he who first planted the idea that rural school consolidation could be a powerful adjunct in the building of a "heaven on earth" in Buck Creek. Although Chalice was a strong advocate of rural school consolidation, he realized that most people in the area took considerable pride in their country schools. They certainly did not view their schools as being in any state of impending crisis.

Indeed, the records of the Delaware County school superintendent suggest that the country schools of the area were performing very well. The school buildings were in a good state of repair, enrollments and attendance levels were high, teacher turnover was low, and evaluations of the teachers were strong. ${ }^{29}$ For those families who wanted to send their children on to high school, the Hopkinton high school was only a few miles away. Practically everyone had close friends or relatives there with whom their children could board throughout the week. The Hopkinton school district contracted with Lenox College, a Presbyterian school, to provide facilities and furnish much of the instruction of its high school students. This added luster to the prospect of attending high school in Hopkinton, at least for Protestant families. Indeed, almost all of the Buck Creek church members who had attended high school had gone to Lenox Academy (as the Hopkinton high school was called), and many of them had attended Lenox College for several terms as well. For Catholic families, there was the new Catholic high school in Ryan (which many had helped pay for with their contributions), or they could continue the long-standing tradition of sending their children to one of several excellent Catholic colleges in Dubuque, which provided secondary as well as higher education.

Rather than tackle the issue of rural school consolidation directly, Chalice first chose to make the activities of the Buck Creek church a central focus in the everyday lives of as many people in the area as possible. Once that had been accomplished, he thought the "inevitability" of rural school consolidation could be faced and the task completed in a manner that would complement and reinforce the church's efforts to build a cohe-

29. These records are available in the Delaware County Historical Museum, Hopkinton. For a detailed discussion of the quality of the country schools in the Buck Creek area, see Reynolds, There Goes the Neighborhood, chap. 8. 
sive and progressive rural community. He wanted the material, social, and cultural advantages of the city to be reconstituted in the countryside and available to farm families rather than for farm families to have to relocate, however temporarily, to the town or city to obtain them. In this he had the full complicity of several of the key patriarchs in the Buck Creek church. Although Chalice did not attempt to hide his support for modern, up-todate education in consolidated schools, he stopped short of openly agitating for the formation of an open-country consolidated school district at Buck Creek. To have done otherwise would have jeopardized his ministry. Instead, he worked behind the scenes to encourage leaders in the Buck Creek church to take up the cause of mobilizing support for building a consolidated school at a site on the hill behind the new parsonage. He believed that once the consolidated school was built at that location, stores and other economic activities would agglomerate to create a village at the site. ${ }^{30}$

As long as the operation of rural schools in the Buck Creek area remained the prerogative of the various neighborhoods, the religious affiliation of families in a neighborhood was seldom an issue of contention. On those few occasions when it was, voters in that neighborhood usually chose a different school director for the subdistrict at the next annual meeting. Although directors were always prominent men in their neighborhoods, they still had to behave like neighbors; that precluded favoring one religion or denomination over another in the operation of their school. If a neighborhood was predominantly Catholic, the director was usually a Catholic and vice versa for Protestant neighborhoods. Nevertheless, religious affiliation was seldom the conscious criterion used by neighbors in selecting a director. If there was any self-conscious consideration of religion in school politics at all, it was in the selection of the officers of the board. Maintaining religious balance among the officers helped ensure that no group could dominate in setting the townships'

30. Chalice seems to have convinced many people that this would be the inevitable result of the Buck Creek church's community-building endeavors, including even the State Deputy Superintendent of Public Instruction. See Frank D. Joseph to F. P. Walker, 2 June 1915, Letter Books, Superintendent of Public Instruction, State Archives, State Historical Society of Iowa, Des Moines. 
general educational policy. This amounted to a politics of accommodation, but it also made any change in policy difficult when the attitudes of Protestants and Catholics toward public schooling diverged. Until rural school consolidation became an issue in the area, however, no significant divergence had occurred. That changed when rural school consolidation was forced onto the local agenda in 1915.

In that year, state leaders, with the support of the Methodist church and local businessmen, were finally successful in getting a local consolidation movement underway in Earlville, a small town about 12 miles northeast of the Buck Creek church. Soon, similar movements were underway in most other small towns in the eastern half of Delaware County, including Delhi and Hopkinton. ${ }^{31}$ Chalice and the leading patriarchs of the Buck Creek church decided that the time had come for them to initiate their own consolidation movement in Union Township, if only to thwart the loss of Buck Creek territory to consolidated school districts centered on either or both of those towns. They were particularly concerned about the possibility of losing to Hopkinton any territory that might eventually be included in Buck Creek's own consolidated district. The successful mobilization of Buck Creek opposition, coupled with resistance from farmers in other outlying districts and rumors about the possible closure of Lenox College (and Academy), resulted in the failure of the consolidation effort at Hopkinton in August 1915. ${ }^{32}$

As the impetus provided by the threat of Hopkinton usurping potential Buck Creek territory faded, Chalice's priority shifted to convincing church leaders that the long-term success of their community-building project required the abandonment of the area's one-room schools and their replacement with a consolidated school near the Buck Creek church. The school would contain a full four-year high school program as well as elementary grades. By early December 1916, Chalice had apparently garnered enough support for the project to kick off what he dubbed the "Great Forward Movement." It consisted of a series of spe-

31. See Reynolds, There Goes the Neighborhood, chap. 7.

32. For a discussion of the failed Hopkinton attempt, see Reynolds, There Goes the Neighborhood, chap. 8. 
cial meetings designed to celebrate the church's past accomplishments and to expand the scope of its community-building efforts by reigniting interest in rural school consolidation. ${ }^{33}$

Chalice and his parishioners appeared confident that what they had accomplished in the way of rural community building in Buck Creek could provide an example for other rural churches. Buck Creekers had solved the rural church problem on their terms and had gained national attention for their pastor and their community. Professor Paul L. Vogt, national superintendent of rural work in the Methodist Episcopal Church and a leader in the national Country Life movement, visited Buck Creek in April 1917. Vogt, who was collecting information on "the best results of rural and village church work in all parts of the country," had been informed of Chalice's work and decided to see it firsthand. He spent several days visiting with Chalice, collecting some of the materials he wanted to include in a publication chronicling Chalice's success. Vogt was not disappointed with what he saw and heard. When he spoke at the Sunday morning service in the Buck Creek church, he congratulated the congregation for its outstanding work in solving the rural church problem. He also offered some suggestions for continued success. Some of Vogt's observations were eventually published in the booklet, Buck Creek Parish, which was distributed widely to Methodist churches throughout the country for a number of years. ${ }^{34}$

The Buck Creekers' confidence in their community-building efforts prepared them to use the church as a force for social change in the educational arena as well. They sought to solve the rural school problem in essentially the same way as they had the rural church problem. The rural school would be revitalized by forming a consolidated school district coincident with the larger Buck Creek community. All members of the community, Catholic and Protestant alike, would have the advantages of a town or city school, although the school itself would be located in the country.

33. The Hopkinton Leader, 6 December 1916, carried a lengthy article, apparently written by Chalice, on the Great Forward Movement.

34. Hopkinton Leader, 12 and 19 April 1917. Given Vogt's perspectives on rural sociology published in the same year, in his Introduction to Rural Sociology (New York, 1917), his suggestions almost surely included rural school consolidation. 
As 1917 began, the politics of accommodation, which had previously characterized the operation of the township's schools, gave way to a different kind of politics. Henceforth, Catholics and Protestants alike realized that the Buck Creekers aimed to make Buck Creek a Methodist place, to make Buck Creekers of everyone in the area. Initially, however, opposition to consolidation from among a few key members within the Buck Creek church itself still had to be overcome. Not all members were ready to jeopardize the good relationships they enjoyed with their Catholic neighbors.

IN THE SPRING OF 1917, just when Chalice and the Buck Creek church leaders were ready to launch a formal drive to establish their consolidated school district, the United States entered World War I. The effort to form a consolidated school district at Buck Creek had to be shelved. The patriotic fervor surrounding the U.S. entry into the war swept through midwestern farm communities, including Buck Creek. ${ }^{35}$ Almost immediately Chalice introduced the theme that would remain the dominant one for the remainder of his pastorate at Buck Creek-that it was the duty of American farmers to help win the war by dramatically increasing food production. Aiding the Allied war effort through increased agricultural production displaced rural school consolidation as the principal goal of Buck Creek's community-organizing initiatives. Like others espousing the Country Life philosophy, Chalice believed that the food shortages induced by the war would finally lead to the realization that continued industrialization and urbanization in the United States could not be sustained if the social conditions of rural life continued to languish compared to those of the cities.

During the spring of 1917, Chalice initiated what turned out to be the first step taken in Delaware County toward obtaining a county agent under the Smith-Lever Act of $1914 .^{36} \mathrm{He}$ also participated in one of a series of "conservation conferences"

35. In one of Chalice's first sermons after the declaration of war, titled "Was Jesus in Sympathy with War?", he argued that Christ would have been in sympathy with the Allies in the war effort. Hopkinton Leader, 26 April 1917.

36. Hopkinton Leader, 17 May 1917; Buck Creek Parish, 18. 
that the U.S. government organized throughout the Midwest to identify and coordinate local efforts for achieving vast increases in food production. Upon his return, he gave a series of rousing addresses, beginning with one at the Buck Creek church, followed by repeat performances before the commercial clubs of Manchester and Hopkinton. His theme at each was how to organize farmers and farm workers throughout the county to support the war effort. He urged the expansion of crop acreage and outlined a plan for organizing a county labor bureau to recruit and allocate farm workers to farms to minimize crop loss during the fall harvest. As he put it, "America is not fighting for territory or money, but to protect the democracy of the world. Every man, woman and child must do his bit. ${ }^{\prime \prime 37}$

At the Manchester meeting, he announced that a labor committee and other committees to plan and implement the project had been appointed for the Hopkinton and Buck Creek areas. He urged other communities in the county to follow Buck Creek's example. Although this form of organizing had the secular goal of mobilizing agricultural production to "win the war," its leadership and style remained firmly identified with the Buck Creek church. No Catholics from Union Township were appointed to the labor committee. The only Catholic asked to serve in any capacity on any committee was Chalice's friend Frank King, who was appointed to the lowly publicity committee, along with five Buck Creekers. Soon commercial clubs had organized the rest of the county into a series of similar labor committees to coordinate the allocation of farm labor during the harvest season. ${ }^{3 k}$ This system for deploying farm workers remained in effect for the duration of the war.

By fall 1917, Buck Creekers could claim that Buck Creek was the most "progressive" farm community in Delaware County and get no argument from the county's business leaders. The Buck Creek church's activities during the war had helped forge a new identity for Buck Creek and helped transform the nature of class consciousness ampng the farmers of the area as well. Buck Creek farmers and area businessmen had reorganized farm

37. Hopkinton Leader, 10 May 1917.

38. Ibid. . 
labor to help "win the war," while also helping farmers enter the ranks of the middle class as global commodity producers. ${ }^{39}$

As for Chalice, he moved on to a bigger stage. He left Buck Creek in the fall of 1917 to become a field superintendent for the Methodist Episcopal Church, to head up that church's efforts to revitalize its rural ministry in the Midwest while at the same time taking charge of a much larger parish in West Branch, just a few miles east of Iowa City. ${ }^{40}$ His mission at Buck Creek was over, or so it seemed.

In 1918 and 1919, neither the Buck Creek pastors nor the Buck Creek community captured any headlines in the local press. Chalice's replacement, William Baker, came highly recommended from the Methodist Episcopal Church in Mechanicsville, but he was unable to pick up where Chalice had left off in carrying forward with the reform of rural community life. $\mathrm{He}$ resigned within the year. His replacement, W. A. Odell, fared no better and was not reappointed for a second year. Chalice had left very big shoes to fill. Until the arrival of a Chalice protégé, A. R. Grant, in October 1919, nobody could fill them. ${ }^{41}$

IN GRANT, the Buck Creek church's board of trustees recognized many of Chalice's virtues-youth, an old-time evangelistic style, and a commitment to obtaining all the conveniences and advantages of urban life for farm families while avoiding the disadvantages. Furthermore, he came highly recommended by Chalice himself. ${ }^{42}$ Chalice maintained close personal ties with many people in the Buck Creek church, and he and his family frequently returned to the area for short visits. No doubt he also maintained a keen interest in the success of the communitybuilding effort he had begun but did not fully complete in the Buck Creek area. The district superintendency Chalice had accepted also entailed heading up rural parish work in the Iowa conference for the Board of Home Missions of the Methodist

39. This point is developed and documented at some length in Reynolds, There Goes the Neighborhood, chap. 8.

40. Hopkinton Leader, 4 October 1917; Manchester Press, 11 October 1917.

41. Hopkinton Leader, 11 October 1917; Manchester Press, 10 October 1918.

42. Mrs. Gertrude Green, interview by author, Hopkinton, 30 August 1991. 
Episcopal Church. ${ }^{43}$ Buck Creek remained the centerpiece, the exemplar, for this work; hence, his continued success in this capacity was still linked to Buck Creek.

Chalice's success in building up the membership of the parish through his combination of Country Life progressivism and traditional Methodist revivalism had won national attention for Buck Creek and regional visibility for him in the new field of religious sociology. His leadership in forging a coalition between farmers and business people to effect higher agricultural production and the more widespread adoption of food conservation measures had also won him regional and statewide attention in rural sociology. ${ }^{44}$ Rural school consolidation had been dislodged from its position atop the reform agenda of Chalice and his Buck Creek followers by the seductive combination of progress, profits, and patriotism. The issue remained alive but dormant.

Rev. Grant lost no time in returning the issue of rural school consolidation to its previous prominence in the reform agenda of Buck Creekers. In doing so he received a great deal of help from the state's Department of Public Instruction (DPI) and the Iowa State Teachers' Association (ISTA). During the spring of 1918 , the DPI and the ISTA had been successful in pushing legislation through the General Assembly designed to make consolidation more attractive and easier to accomplish politically. By the time Grant arrived in Buck Creek in the fall of 1919, the ISTA, with political support from the DPI, had already begun a massive campaign to complete rural school consolidation in the state. ${ }^{45}$ The ISTA was ready to supply written materials on consolidation, stereopticon slides of consolidated schools across the state, speakers, forms to be used in organizing consolidation drives, and free legal advice. The campaign was aided immeasurably by the hyperinflation of land values, high agricultural commodity prices, and the lure of middle-class modernity

43. Hopkinton Leader, 26 July 1917 and 4 October 1917.

44. The Hopkinton Leader, 21 June 1917 reported that "The Reverend Gilbert Chalice is at the State College at Ames, where he will give a series of lectures on Rural Sociology. A large number of ministers and leaders in rural life are expected from all over the state."

45. See Reynolds, There Goes the Neighborhood, chap. 5. 
seemingly ensured by continuing prosperity. ${ }^{46}$ In its pamphleteering and exhortation, the consolidation campaign in rural areas was rivaled only by the efforts of the U.S. Department of Agriculture to sign up farmers as members of the Farm Bureau. ${ }^{47}$

It was not long before it was clear that a consolidated school district of 16 sections-the minimum permitted by law-could probably muster sufficient voter support in the school subdistricts in the area dominated by members of the Buck Creek church. However, it was equally obvious that a district that small could not raise enough tax revenues to build, staff, and maintain a consolidated school comparable to others being created in small towns across the state. The conclusion was inescapable. If Buck Creek was to have its own consolidated school, neighborhoods in which Catholics predominated would have to be included in the consolidated district. The obvious problem with this was that it would surely result in politicizing the consolidation issue in Methodist versus Catholic terms. It would also risk rending asunder the long-established neighborhood relationships between the two groups based on spatial proximity.

The key question for members of the Buck Creek church was whether the community and educational benefits of consolidation outweighed the costs of at least a fourfold increase in school property taxes and the further destruction of neighborhood relations with Catholic families in the area. For most Catholics in the vicinity, the question of whether the benefits of consolidation outweighed the costs was not worth considering. In neighborhoods where Catholics predominated, it was clear that voter support for consolidation would be practically nonexistent. Catholic parents saw few, if any, benefits of any consolidation proposal that ensured Methodist hegemony over the education of their children. For the previous five years they had witnessed their exclusion from much of the social life of the Buck Creek community and their growing marginalization in its political and economic affairs. In the politics of place practiced in Union Township, and increasingly in the rest of Delaware

46. Ibid., chap. 9.

47. Manchester Press, 27 November 1919. 
County as well, differences in religion were already politicized. ${ }^{48}$ Efforts to revitalize rural life in the county structured around the rural or village church practically guaranteed that result. Grant and the Buck Creek church leaders pushed ahead with their plans for school consolidation nonetheless.

AS THE MEMBERS of the Buck Creek church sought to build support for rural school consolidation during the spring of 1920 , the activities of another organization began to compete for their attention. Seeking to gain a foothold in lowa by exploiting the anti-Catholic sentiment that had developed over consolidation, but apparently also recognizing in Buck Creek fertile ground for furthering its own social agenda, the Knights of the Ku Klux Klan secured a member of a well-known family in the Buck Creek church to be the Klan's local organizer-the "kleagle." A drive to enlist members by staging local rallies was soon under way. The extent of Grant's complicity in Klan activity is not clear, but there is no doubt that he did not discourage it either publicly or privately. Most Catholic families in the area believed the widespread rumor that Grant would "whoop it up for the Ku Klux Klan right from the pulpit.."

The traditional interpretation of the rise of the Klan in the Midwest in the 1920 s is that it was a backward-looking, antimodernist reaction to increasing industrialization, encroaching urbanization, and the apparent destruction of rural values. According to this view, the attraction of the Klan to many rural midwesterners, especially farmers and workers marginalized by the changes swirling around them, was that it offered the promise of restoring traditional rural values. It did so by redirecting the xenophobia, developed during World War I, against a set of internal "foreigners"-Catholics, Jews, African Americans, and other urban immigrants-who seemed to threaten the

48. See Reynolds, There Goes the Neighborhood, chap. 7.

49. Anonymous, interview by author. Without exception, all of the persons interviewed in the Buck Creek area volunteered that the KKK wielded influence in the Buck Creek parish during the period and that the school consolidation controversy was the spark the Klan exploited in its anti-Catholic activities in the area. 
preservation of those values. ${ }^{50}$ Although the Klan's activities in Buck Creek became increasingly anti-Catholic over time, they did not seem to start out that way. Instead, support for the Klan in Buck Creek appears to have been more an expedient adjunct in a community-building project completely compatible with that of the Klan's larger social agenda. As recent scholarship has shown, the Klan had great appeal among a broad cross-section of Americans in the 1920s in part because it possessed many of the trappings of the mainstream reform movements of the period. ${ }^{51}$ Although enforcement of Prohibition appears to have been the principal issue championed by the second Klan, the need for educational reform to remedy the ills of the public schools, especially those in poor or rural areas, was the next most important social issue emphasized by the Klan. ${ }^{52}$

The rise of the Klan in Buck Creek was linked most closely with the exploitation of a local conflict over consolidation and

50. Two of the more influential traditional interpretations of the rise of the 1920s, or second, Klan are John Moffatt Mecklin, The Ku Klux Klan: A Study of the American Mind (New York, 1924); and Charles C. Alexander, The Ku Klux Klan in the Southwest (Lexington, KY, 1965). More recent, but similar treatments include David H. Bennett, The Party of Fear: From Nativist Movements to the New Right in American History (Chapel Hill, NC, 1988); and Wyn Craig Wade, The Fiery Cross: The Ku Klux Klan in America (New York, 1987). For a recent review of the "traditional" interpretation of the Klan and a criticism of it based on a number of recent "revisionist" studies focusing on the Midwest and West, see Leonard J. Moore, "Historical Interpretations of the 1920s Klan: The Traditional View and Recent Revisions," in Shawn Lay ed., The Invisible Empire in the West: Toward a New Historical Appraisal of the Ku Klux Klan of the 1920s (Urbana, IL, 1992), 17-38. Important revisionist studies include Robert Alan Goldberg, Hooded Empire: The Ku Klux Klan in Colorado (Urbana, IL, 1981); Leonard J. Moore, Citizen Klansmen: The Ku Klux Klan in Indiana, 1921-1928 (Chapel Hill, NC, 1991); Kathleen M. Blee, Women of the Klan: Racism and Gender in the 1920s (Berkeley, CA, 1991); and William D. Jenkins, Steel Valley Klan: The Ku Klux Klan in Ohio's Mahoning Valley (Kent, $\mathrm{OH}, 1990$ ).

51. Kathleen Blee, Women in the Klan, 177, characterizes the Klan in the 1920s as "a reactionary, hate-based movement with progressive moments." Other historians reach similar conclusions. For example, Leonard Moore, Citizen Klansmen, 191, argues that the 1920s Klan movement was "triggered, in good part, not by disillusionment with progressivism, but by a yearning to fill the void left by its demise." William Jenkins, Steel Valley Klan, ix, suggests that in its response to the cultural conflicts deriving from rapid industrialization and urbanization, the Klan was a culmination of the Progressive movement.

52. Moore, Citizen Klansmen, 36-38. 
does not appear to have exploited any latent preexisting antiCatholic sentiment peculiar to the area. However, the Country Life gospel as preached by Chalice and Grant bore a striking resemblance to what the revisionist work on the Klan of the 1920s has identified as that movement's central tenets. ${ }^{53}$ Rather than purely reactionary and backward looking, the communitybuilding project of the Buck Creek church was more explicitly Janus-faced. That project was backward looking in its exaltation of farm life and some traditional rural values but forward looking in its insistence on maintaining traditional values under changed social relations and material conditions of rural life. Rural life was to be of the city but in the country. Anti-Catholic feelings were triggered by the realization among Methodists that Catholics, by their rejection of rural school consolidation, could frustrate the fulfillment of that project. The likelihood that the community-building program of the Buck Creek church would erupt into Catholic-Protestant conflict sooner or later should have been apparent right from the beginning. In the attempt to make Buck Creek a Methodist place, Catholic families were denied a role, as Catholics, in that place's future even though they, every bit as much as the Methodists, could lay claim to having shaped its history since the earliest days of European settlement.

Once a significant number of Buck Creekers had joined the Klan, the nature of the controversy over rural school consolidation changed dramatically. In the late spring and early summer of 1920, however, the Klan was just gaining a foothold in the area. Initially, local Catholics reacted to growth in Klan membership among Buck Creekers with little apparent alarm. For one thing, the Klan was a new phenomenon in Iowa; indeed, its activity in Buck Creek appears to have been one of the Klan's

53. Indeed, the rise of the Klan in Buck Creek can be more appropriately interpreted as a concrete social product of the Country Life movement's variant of progressivism rather than as a radical aberration. Obviously, more localitybased studies of the Klan and its involvement in helping to implement rural school consolidation and other reforms advocated by the leaders of the Country Life movement during this period are necessary in order to determine the extent to which the Buck Creek case was typical of what was occurring in other rural communities in lowa. 
earliest attempts to recruit members in Iowa. ${ }^{54}$ Many in the Buck Creek area tried to shrug it off as an unpleasant fad, even a new form of rural social activity designed to help enliven an otherwise dull rural existence. Some saw it as a moneymaking scam, either to help line the pockets of particular individuals or to pad the coffers of the Buck Creek church. As one Catholic who later became active in fighting the consolidation proposal put it, "A lot of the boys that joined the Klan, they reached in their pocket and paid their dues and that's the last they saw of them. It was a sucker deal. ${ }^{\prime \prime 5}$ One thing, however, is clear. The Klan became increasingly attractive to Buck Creekers as the controversy surrounding consolidation deepened.

From early May 1920 onward, as the petitions to form a consolidated school district in the Buck Creek area were circulating, interest in the Klan grew among the Buck Creekers. As it did, conflict over the formation of a consolidated school district intensified and increasingly took on religious overtones. Indeed, some people were unable to distinguish between the social activities of the Buck Creek church supporting the consolidation drive and similar activities by the Klan. Simply put, it appears that the Klan became the clandestine arm of the Buck Creek Brotherhood, the men's club of the Buck Creek church. Speakers at Klan rallies argued that Catholics in the Buck Creek area were opposed to the fully American, rural-minded, consolidated school for one of two reasons. Catholics either wanted to retain the country schools to save money for the education of their children in parochial schools, or they wanted to retain the country schools so they could convert them into de facto parochial schools run and taught by Catholics. Such rhetoric fueled the false rumor among Buck Creekers that the Castle Grove Parish operated a parochial high school behind their church. The fact was that the old school building there had not been used as a school for more than two decades. ${ }^{56}$

54. See Kay Johnson, "The Ku Klux Klan in lowa: A Study in Tolerance" (M.A. thesis, University of Iowa, 1967).

55. Tumey, interview.

56. Cedar Rapids Gazette, 11 November 1962; Sister Joan Marie Delay, "The History of the Immaculate Conception Parish," 1969 (mimeographed copy provided by its author). 
IF ORGANIZERS THOUGHT that it would be an easy matter to obtain the requisite number of signatures, they were in for a surprise. In only three of the nine country school subdistricts included in the proposed district-those where the Buck Creek church membership was concentrated-was the task of securing signatures relatively easy. Even in those areas there were some surprises. Cliff Willard, a landowner, respected member of the Buck Creek church, and former director of the Buck Creek country school, refused to sign. With the excellent Lenox Academy only a few miles away, he was not convinced that the Buck Creek parish needed its own high school. He also thought it unfair to force his many Catholic friends and neighbors in Upper Buck Creek into a consolidated district against their will. ${ }^{57}$

In other subdistricts it was primarily those who were members of the Buck Creek church who signed the petition. It is not known precisely how many qualified voters actually signed petitions in the territory of the proposed district. Either there were not enough, or leaders feared that the proposed district included too many opponents to have any expectation of success in an election. Just when it appeared that the petition drive would need to be scrapped, Grant reminded the Buck Creek church leaders what had worked for them eight years earlier when the issue had been the survival of the Buck Creek church itself-an old-fashioned Methodist revival led by Gilbert Chalice. ${ }^{58}$

Chalice was then posted at West Union in nearby Fayette County. Grant had joined him there for a series of revival meetings over a two-week period in late March and early April. Chalice's relationship with Grant and his continuing interest in the success of the school consolidation project at Buck Creek made it relatively easy for Grant to enlist his help in leading off the equivalent of a camp meeting revival to rekindle and expand enthusiasm for school consolidation. Chalice agreed to "preach" at Buck Creek on Monday evening, June 28, in what was billed as the first in a week-long series of "special meetings" to be held "in the interest of the church and Sunday school."

57. Willard, interview.

58. Hopkinton Leader, 1 July 1920.

59. Ibid. 
Special meetings, indeed. The topic at each meeting was rural school consolidation, and Grant and laypersons in the church spoke almost nonstop on its behalf every night throughout the week. Rather than asking people to come forward and profess their faith at the end of the service each evening, as was typical at revival services, people were urged instead to come forward and sign the new petition for the creation of the Buck Creek Consolidated School District. The tactic worked. By the end of the week enough signatures had been obtained for the proposal to go forward. The petitions were filed with $\mathrm{W}$. A. Ottilie, the county superintendent, on July $23,1920 .^{60}$

Ottilie set August 11, 1920, as the deadline to receive "objections to the boundaries or to the formation of the district." All told, 41 people officially protested the formation of the district in writing. Twenty-nine of them were Catholics. Of the 12 Protestants signing petitions protesting the formation of the district, 9 lived in predominantly Catholic neighborhoods. Although Catholic parents did voice their skepticism about the success of the community-building program of the Buck Creek church, they knew that it would be futile to protest the formation of the district on the three grounds that troubled them most: that they would be turning the control of their children's education over to a Methodist community that had shown no sensitivity to the wishes of Catholic families; that the Buck Creekers had failed to repudiate the anti-Catholic activities of the Ku Klux Klan in the area; and that the proponents of consolidation had included predominantly Catholic neighborhoods in the proposal solely because they needed the additional tax base to build their consolidated school. Instead, Catholics protested the formation of the district on the politically more acceptable grounds of cost, fiscal responsibility, property value depreciation, and the poor condition of the roads over which children would need to be transported. Ottilie found none of the objections meritorious and set the election on the formation of the district for September $13,1920 .^{61}$

60. Willard, interview; Records of the Delaware County Superintendent, County Auditor's office, Delaware County Courthouse, Manchester.

61. Records of the Delaware County Superintendent; Hopkinton Leader, 2 September, 1920. 
In the week before the election, most political pundits thought the issue would lose, but by a narrow margin. ${ }^{62}$ Because the territory proposed for inclusion contained no independent town or village school district, only a simple majority vote of the electors was required for the issue to pass. Buck Creekers pulled out all the stops in an effort to push the issue over the top. Grant, in particular, staked the success of his pastorate on its passage. Both from the pulpit and in personal visits with those people thought to need a "little nudging," he called on all members of the parish to vote "yes." Professor Earl Roadman, head of the new Rural Life Department at Upper Iowa University, a Methodist college about 50 miles northwest of Buck Creek, was scheduled to give a keynote address on rural school consolidation on the first day of the Buck Creek Fair on September 8. Macy Campbell, the new head of the Rural Education Department of the Iowa State Teachers College and the state's leading proponent of rural school consolidation outside the Department of Public Instruction, was to close the fair on September 12, the eve of the election, by speaking on the community benefits of rural school consolidation. The issue of the Hopkinton Leader announcing these events also contained an editorial urging voters to support consolidation: "Every voter in the proposed Buck Creek district should ponder deeply his obligation to his own family and to his neighbors before he determines to oppose the proposition next Monday. The moral obligation is a hard one to dodge." ${ }^{63}$

The stage appeared set. In his election eve address, Campbell depicted opponents of consolidation as greedy, myopic, educationally backward, unpatriotic, and even immoral. ${ }^{\text {it }}$ As people filed out of the Buck Creek church after the speech, they were startled to see a large cross set ablaze on the hill next to the cemetery about 150 yards west of the church. A small group of men with white hoods and robes cheered, then piled into an automobile and sped northward on the road toward Delhi. One

62. Hopkinton Leader, 16 September 1920.

63. Hopkinton Leader, 2 and 9 September 1920.

64. Campbell had given a similar address earlier in the year in Manchester at a Farm Institute meeting sponsored by the Farm Bureau. See Manchester Press, 15 January 1920. 
person in the crowd was heard to exclaim, "The fools. They've gone too far." ${ }^{165}$ The results of the election the next day perhaps told another story. The cross burning at Buck Creek may have reminded Buck Creek Methodists who might otherwise not have been convinced of the merits of consolidation that the election was about who was to wield power in the area-Protestants or Catholics.

The editor of the Leader apparently saw no purpose in reporting the cross burning in its next issue. Instead, he reported, "practically every qualified voter in the proposed territory attended the polls. ... The issue looked doomed to defeat in the weeks before the election. . . . But as the good points of consolidation were presented, one after another of the objections were battered down and numerous voters changed from a negative to an affirmative position when convincing facts were given them." The final tally was 133 for and 76 against, with 6 spoiled ballots. ${ }^{66}$ The Leader opined that a new school could be built and opened by the next fall, "should everything work harmoniously." The Manchester Press carried a similar piece but also indicated that "the new school will be located near the church. This will mean greatly improved facilities for the children of the neighborhood, and we congratulate the good people of Buck Creek upon the wisdom and enterprise shown by them. ${ }^{167}$ Lost in the hoopla was any mention of the apparent shift in the power relations between Methodists and Catholics in the area. Buck Creek was now a formally constituted, legally recognized place-a Methodist place. Or so it seemed to be.

As required by law, the county superintendent posted notices in the Leader calling for the nomination of directors and a

65. Green, interview.

66. Hopkinton Leader, 16 September 1920. Prior to the election a considerable amount of interest had arisen over what the voting split between men and women would be on the issue. The Monticello Express, 23 September 1920, carried a piece opining that women would probably be less influenced "by the dollars and cents" than the men would be. In the final count, however, the difference between men and women was negligible. Seventy-three men voted for the proposition and 44 against, with 2 spoiled ballots (61.3 percent in favor), while 60 women voted for and 32 against, with 4 spoiled ballots (62.5 percent in favor).

67. Hopkinton Leader, 16 September 1920; Manchester Press, 16 September 1920. 
treasurer for the Buck Creek Consolidated School District. He set the election for October 5, 1920. A slate of five directors was nominated from among the Buck Creek church members, while James Johnson, the longtime treasurer of the Union Township school board, was nominated for treasurer. Catholic voters nominated only one candidate, and, as a protest, most voted only for him, boycotting the Buck Creek slate. The Buck Creek church slate won. ${ }^{68}$

THE NEW BOARD MEMBERS were well aware that Catholic families in the area were angered by the results of the consolidation election and by the tactics employed to intimidate voters into supporting the proposition, especially the $\mathrm{Ku} \mathrm{Klux} \mathrm{Klan}$ cross burning on the eve of the election. They had also heard rumors that neighborhood leaders in the Upper Buck Creek, Dufoe, Rose Hill, Wilson, and Harrington neighborhoods had gotten together and retained a lawyer to explore what legal action they might pursue in the matter. ${ }^{69}$ However, they were caught off guard on November 13, when M. J. Yoran, the Delaware County Attorney, filed suit against the Consolidated Independent School District of Buck Creek and its directors, arguing that the district was in fact not a legal corporation and that its directors were acting illegally. ${ }^{70}$ They were even more surprised when the district court agreed with the County Attorney and declared the district illegally formed because its boundaries did not conform to those of preexisting subdistricts. If the Buck Creek Methodists were to have their consolidated school, they would have to start the process all over again. This they did.

The formation of a consolidated school district in the Buck Creek area had been something of a crusade for the Buck Creek Methodists for almost a year. After the cross-burning incident at the Buck Creek Fair, Catholic opposition to consolidation assumed

68. Hopkinton Leader, 7 October 1920.

69. Indeed, they had banded together. The Catholic churches in Castle Grove, Ryan, and Delhi had all taken up special collections to help pay the legal fees. They continued to do so for the next several years. Tumey, interview.

70. Case No. 4796, Delaware County District Court, December Term 1920, Delaware County Courthouse, Manchester. 
FIGURE 2

THE BUCK CREEK CONSOLIDATED SCHOOL DISTRICT, 1921
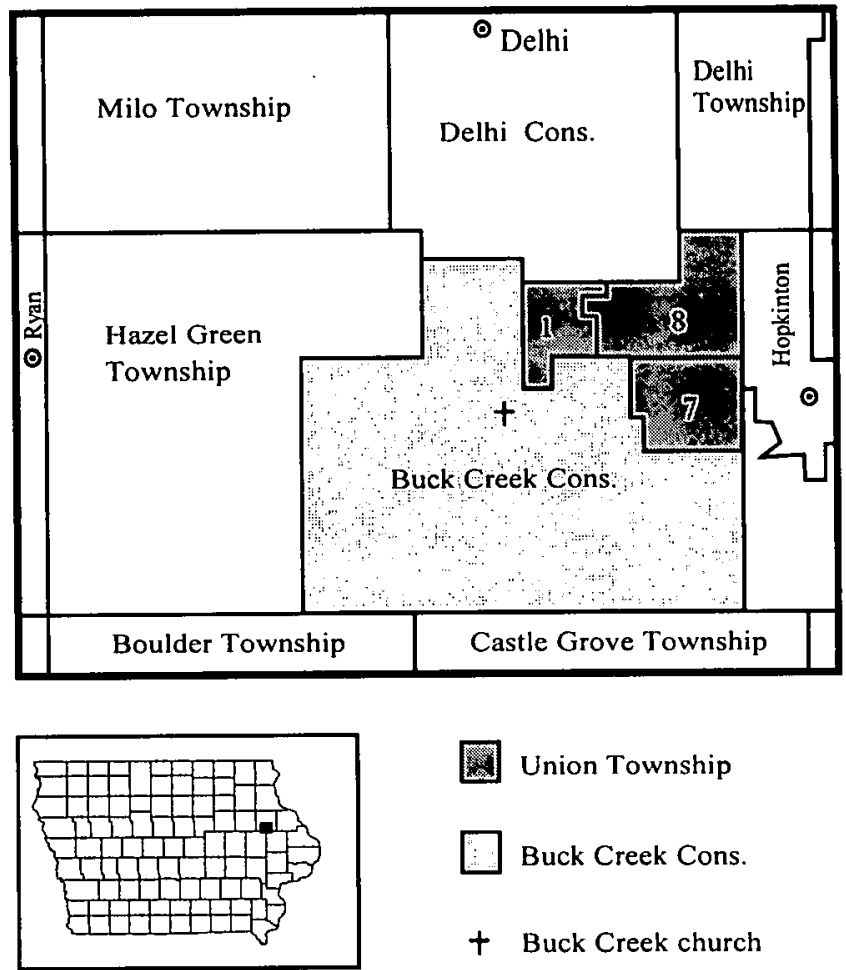

Union Township

Buck Creek Cons.

$+\quad$ Buck Creek church

Map by Peter Li

a similar form. From that time onward, Catholic families, like their Methodist neighbors, increasingly thought of the controversy in Catholic versus Protestant terms. If Catholic families wished to preserve their country schools, they had little choice but to mobilize as Catholics, not simply as members of particular rural neighborhoods. Buck Creekers were already mobilized as Methodists, and with apparent victory on the consolidation issue seemingly snatched away by the district court, anti-Catholic feelings among them intensified dramatically. Within a matter of a few weeks, the Ku Klux Klan had signed up almost every man 
in the Buck Creek church with ten dollars in his pocket. As Buck Creekers flocked to the Klan, cross burnings became commonplace. Among Catholics, suspicions ran high. Lifetime friendships dissolved as Catholics suspected their Protestant neighbors of belonging to the Klan. Even lifelong friends and neighbors Warren Winch and "Jimmy" Kehoe, who had served as president and secretary, respectively, of the Union Township school board for the preceding decade, no longer spoke to each other. ${ }^{71}$

Proponents of consolidation once again carried a hotly contested election. Still, the matter was contested in the courts and in the rural neighborhoods of the area for the next two-and-ahalf years. The legality of the district was finally resolved on February 17, 1923, when the state supreme court ruled that the Buck Creek Consolidated Independent District had been legally organized in the second election held on the issue (fig. 2). ${ }^{72}$ The social scars, however, lingered much longer.

FROM 1925, when it graduated its first class, until it was closed in 1959, 345 students graduated from the twelfth grade of the Buck Creek Consolidated School-an average of just under ten per year. The largest graduating class was 19 in 1944 and the smallest was 4 in 1931. In 1924, 20 students graduated from the school's eighth grade. Of those, only seven went on to graduate from the school's twelfth grade. ${ }^{73}$ Like many rural Iowans, farm families in the Buck Creek district wanted to have their own high school even though only a minority of their children would ever graduate from it in the years before the end of World War II. Catholic children in the district attended the consolidated school through their grade school years. They had little choice. Prior to the 1950s, however, very few Catholic children attended the high school grades in Buck Creek, and fewer still graduated from the twelfth grade.

71. Smith, Tumey, and Willard interviews, and an interview by author with an anonymous informant (whose name is withheld by request), Hopkinton, 24 August 1994.

72. State v. Consolidated Independent School District of Buck Creek, Delaware County, 195 Iowa 637 (1923).

73. Records of the Buck Creek Consolidated School, Delaware County Historical Museum, Hopkinton. 
Catholic families began leaving the district in increasing numbers. As they did, their places were taken by Protestants, most of whom became affiliated with the Buck Creek church. With the onset of the Great Depression, and the decreased ability of farmers to make their mortgage payments, the departure of Catholic families was hastened still further. The residue of bad feelings between Catholics and Protestants caused by the zealotry of the Buck Creekers in their drive to consolidate the rural schools in the area rendered Buck Creek an undesirable place for Catholic farm families.

Interest in the Buck Creek school heightened considerably in 1930, when the Buck Creek boys' basketball team won the Class B district tournament in Manchester and went on to earn two more victories over larger schools before losing in the regional championship game. As recorded in the local press, the Buck Creek team made "a truly remarkable showing ... and one to be proud of. The feat has never been duplicated in the annals of Delaware County basketball. . . . People who had never heard of Buck Creek will remember for a long time to come the fine team put out by the school and the country lads who almost annexed the title., ${ }^{.74}$

Buck Creek was no longer a place whose identity derived principally from its past successes in creating a vibrant rural Methodist community and the controversy it spawned over the formation of one of the few purely rural consolidated school districts in the state. Buck Creek was now recognized in the record books of the Boys State Athletic Association, and hence, in a larger popular sense, Buck Creek had arrived historically; it had become a real place. Buck Creekers had shown that new purely rural communities could be forged in the countryside and that their farm boys could compete on even terms with those of the towns. No longer did Buck Creekers have to send their children to Hopkinton for high school.

IF EVER A PLACE was created by following the social policy prescriptions and ideology of the Country Life movement, it

74. From the Dora Winch scrapbooks. The clipping appears to be from the Manchester Press. It is dated simply "1930." 
was Buck Creek. Indeed, for a time it was held up as an example to be followed by those wishing to join the activities of the local churches and the state in building new rural communities capable of transforming the rural Midwest into a more modern agrarian landscape devoid of class conflict. Much was achieved along these lines in the social construction of Buck Creek, but at what cost? Gone was the rural neighborhood as a place where, irrespective of religion, neighbor was linked to neighbor by bonds of reciprocity, mutuality, and propinquity. A modified neighborhood system of family farming continued to operate for the Methodists in the area, as the Buck Creek church assumed institutional responsibility for fulfilling needs that had previously rested with the rural neighborhood. Catholics, however, now found the traditional system undermined severely, if not fatally.

Although the quality of education in the Buck Creek Consolidated School may not have been much better than that provided in the country schools it replaced, the new school did eventually become the center of community life and community pride for most residents of the district, displacing even the Buck Creek church. In the wave of consolidations in the late 1950s, Buck Creekers fought to retain their school. This time they lost. The Buck Creek high school closed in 1959, when the Buck Creek district consolidated with those of Earlville, Delhi, Oneida, Delaware, and Hopkinton and all of the then remaining country school subdistricts in between to form the Maquoketa Valley Community School District. The building was retained as an elementary "attendance center" in the consolidated district until it was finally closed altogether in 1976. Today it stands abandoned.

The lesson that Buck Creek teaches is that rural school consolidation was not really about achieving educational equality between town and country or about enhancing the educational opportunities of farm children. Instead, it became a means of creating a new kind of place, a place where farmers were better, more modern, richer, even more moral than their town cousins -certainly not merely their equals. The school consolidation movement played to creating social superiority and difference, exploiting whatever implicit differences were already at hand. Perhaps that was the only way that family farmers would em- 
brace the educational changes that reformers thought necessary for the survival of a family-based system of agricultural production.

In Buck Creek, rural school consolidation became a means of creating a Methodist place. Elsewhere in the state, the same laws were coupled with a similar community-building logic to help create Catholic places. ${ }^{75}$ The rural school consolidation movement in Iowa was not in principle anti-Catholic. Whatever the case locally, it quickly degenerated into a class movement at the state level. The movement attempted to exploit alternative visions of community and place that were as reactionary as they appeared progressive. It should not be surprising that some, perhaps many, of its supporters joined the Ku Klux Klan. They did, after all, possess similar social and cultural agendas. Unlike in Buck Creek, most farm people in Iowa rejected rural school consolidation, not because they thought it was necessarily poor educational policy but because it was "a provoker of neighborhood contention" and a "disturber of community harmony." They had a point.

75. For example, at Cosgrove in Johnson County and Parnell in Iowa County, Catholic parishes used the school consolidation laws to reinforce and strengthen Catholic communities.

76. Manchester Press, 20 October 1921. 
Copyright of Annals of Iowa is the property of State of Iowa, by \& through the State Historical Society of Iowa and its content may not be copied or emailed to multiple sites or posted to a listserv without the copyright holder's express written permission. However, users may print, download, or email articles for individual use. 